\title{
INTERNATIONAL STUDENTS' MOTIVATIONS AND DECISIONS TO DO A PHD IN CANADA: PROPOSING A THREE-LAYER PUSH-PULL FRAMEWORK
}

\author{
YOUZHANG \\ UNIVERSITY OF TORONTO
}

\author{
MICHAEL O'SHEA \\ UNIVERSITY OF TORONTO
}

\author{
LEPING MOU \\ UNIVERSITY OF TORONTO
}

\begin{abstract}
The study aims to explore which factors influence international students' decision to pursue doctoral studies in Canada. Drawing on the push-pull model and the mechanism of educational decision making, this study uses semi-structured interviews to gather data and explores themes such as political and economic forces, institutional factors, social background and experience, and individual motivation in students' decision making. Our study identifies multiple factors at the individual, institutional, and country levels that influence students' decision making, including students' past experiences, funding, faculty members, and immigration policies. Moreover, it finds that the factors vary by students' regions of origin and disciplines of study. Our findings, focused on international doctoral students in Canada, add to the ongoing conversation about student mobility and add nuances on international students' decision-making process in times of shifting landscape of higher education internationalization.
\end{abstract}

Keywords: Canada, decision making, international doctoral students, push-pull model

\section{Résumé}

Cette étude vise à explorer les facteurs qui influencent la décision des étudiants internationaux de poursuivre des études doctorales au Canada. S'inspirant du modèle « push-pull » et du mécanisme de prise de décision éducative, elle utilise des entretiens semi-dirigés pour collecter des données et explorer des thèmes tels que les forces politiques et économiques, les facteurs institutionnels, le contexte social et l'expérience ainsi que la motivation individuelle dans la prise de décision des étudiants. Notre étude recense plusieurs facteurs individuels, institutionnels et nationaux qui influencent la prise de décision des étudiants. Nos résultats, axés sur les doctorants internationaux, ajoutent à la conversation en cours sur la mobilité étudiante et jettent un éclairage nouveau sur le processus décisionnel des étudiants internationaux à l'approche de la fin de la troisième vague d'internationalisation de l'enseignement supérieur.

Mots-clés : Canada, prise de décision, doctorants internationaux, modèle « push-pull »

\section{Introduction}

We carry out our research at a time when the international education landscape shifts significantly and approaches the end of the third wave of international student mobility (Choudaha, 2017). The United States, the world's historic leader in attracting international students, has experienced a slowdown in international education growth, and is currently facing competition, not only from traditional Anglophone competitors, such as Canada and Australia, but also new destination countries such as China (Institute of International Education [IIE], 2020). Many crises and geopolitical uncertainties complicate the decision making of international students. These include Chinese-Canadian political tensions over the Chinese technology giant Huawei, a sharp rise in Chinese-US tensions, and Brexit, among others (Mascitelli \& Chung, 2019). More recently, the COVID-19 pandemic 
has added more uncertainties in the field of higher education internationalization. At the same time, Canada, joined by higher education institutions (HEls) interested in reaping the benefits of internationalization, has made immigration a national priority (Government of Canada, 2020). These larger geopolitical tensions, in addition to the pandemic, might affect international student mobility.

Scholars have extensively explored factors affecting international students' decisions to study abroad (see Chen, 2016; Jafar \& Legusov, 2021; Wu, 2020). The most dominant framework considers push-pull factors, such as the attraction of overseas education or lack of program availability in students' home countries (Mazzarol \& Soutar, 2002). However, this framework pays inadequate attention to the impact of the political environment on students' attitudes toward destination countries and individual-level factors such as students' social background and individual motivation. Students compare which countries as they consider studying abroad (Chen, 2007); therefore, it is important to pay attention to national policies. Yet, studies have also shown that national policies affecting international students seem to have little impact on overall student numbers (Sá \& Sabzalieva, 2018). Therefore, the impact of the geopolitical environment and national policies on international students is still debated in the field. We argue that more severe recent changes in the global political environment might have an adverse effect on students' attitudes and decision making. This could affect the number of international students in certain countries, and ultimately the international student mobility landscape globally. Similarly, Chen (2016) recognizes this weakness of the push-pull model and proposes a three-level framework-micro, meso, and macro-to understand students' decisions to study abroad while acknowledging that much scholarship is needed to understand the meso- and macro-level dynamics.

Against this backdrop, our study explores international doctoral students' motivations to study in Canada using the push-pull model of international student choice (Mazzarol \& Soutar, 2002) as our basic conceptual framework. To expand this framework and address its shortcomings in explaining forces at the meso and macro level, we investigate the influence of various factors such as individual motivation, social background and past experience, institutional features, and political and economic forces. In addition, we flesh out this basic push-pull skeleton with additional layers from Gambetta's educational decision-making mechanism (1984), which examines individual-level decision making amid various external constraints, to better understand the dynamics at the individual level. Through interviews with 20 doctoral students at a large, public, research university in Canada (later referred to as "Canadian University" or "CU"), we explore the following research question: How do institutional features, national political and economic factors, and students' motivation and social background influence the decision making of international doctoral students when they decide to pursue doctoral studies in Canada? To better understand the nuances in students' decision making, we also explore potential variation by students' region of origin and program disciplines.

We find that students are primarily drawn by pull factors at individual, institutional, and country levels, including countries' immigration policies, funding provided by institutions, and individual motivations. Students from different regions display a different mix and ranking of institutional-level, country-level, and individual-level motivations. Interestingly, students from social sciences and humanities tend to give more weight to funding and immigration policies, compared to students from sciences. The study contributes to a more nuanced understanding of the complexity of students' decision making, which is influenced by factors in both the origin and destination countries, institutional features, disciplines, and constraints from an individual's life background and personal experiences.

\section{Literature Review}

International student mobility is not new: students moved around cross-nationally in medieval times in Europe and in Asia centuries ago (De Wit \& Merkx, 2012). That said, massive international student mobility has intensified in the late 20th and early 21st centuries against the backdrop of globalization (Shields, 2013). Over five million students in tertiary education studied in a foreign country in 2017, up from fewer than two million in 1997 (UNESCO Institute for Statistics, 2021). This global flow of tertiary students, however, is uneven and has changed over the past two decades. Western countries, particularly English-speaking countries, attract more studentsmainly from developing countries (Altbach, 2007; Barnett et al., 2016; Chen \& Barnett, 2000).

The landscape is shifting in terms of the top destination countries and the share of international students 
they enroll. While the United States remains the top destination country, its share of international students decreased from $28 \%$ in 2001 to $20 \%$ in 2020 (IIE, 2020). On the other hand, some countries have seen growth in their share, including China, Canada, and Russia (IIE, 2020). For example, the growth of the total number of international students in Canada grew by $15.6 \%$ in 2019 from the previous year, the largest among these three new top destination countries (IIE, 2020).

These changes reflect the importance of international students to destination countries for several reasons. For example, some argue that the Great Recession of 2008 and the resulting financial strain placed on higher education budgets triggered an intense global competition for international students and their tuition fees (Choudaha, 2017). Therefore, numerous countries have implemented policies to attract international students, such as Canada's commitment to retain international students as a type of ideal immigrants in Canada to fill local skilled labour shortages (Sá \& Sabzalieva, 2018).

At the institutional level, international students are desirable for other related reasons. Their tuition fees represent an important revenue stream for institutions, amidst decreasing public funding for institutions (Altbach \& Knight, 2007). In addition, international students are framed as contributing to diversity and intercultural learning on campus amidst a push for global learning and internationalization (Buckner et al., 2020; Pandit, 2013). Finally, international graduate students are particularly valued for contributing to research and innovation (Chellaraj et al., 2008).

Given the contributions of graduate students to funding, research, teaching, and innovation in destination countries, they deserve special attention in the field. However, the literature on international students' motivation to study abroad typically does not differentiate between students' levels of study, treating their motivations as the same. In some sense, regardless of their level of study, international students share common motivations to study abroad. Students may be pushed by the lack of availability of programs or institutions in their home countries and pulled by institutional reputation and social links in host countries (Chen, 2007; Mazzarol \& Soutar, 2002). Students may also be motivated by academic and professional growth, and the prestige associated with a foreign degree (Li \& Bray, 2007).

However, graduate students may have different considerations due to the level of programs (master's or doctoral) and the influence of previous academic and life experiences. In a study of international students in Canadian graduate schools, Chen (2007) found that graduate students tend to prioritize program availability rather than countries when they decide to study abroad. This is different from undergraduate students who prioritize countries when they consider study abroad (Chen, 2007). Therefore, further investigation is needed into what factors inform international graduate students' decisions to study abroad, especially at the doctoral level. Current studies on doctoral students in Canada tend to focus on their experiences, such as their sense of belonging and identity (see Gao, 2019), while rarely asking why they come to Canada in the first place.

Other influences on students' motivations to study abroad involve broader social, economic, and political contexts. Students' decisions may be directly informed by their personal aspirations and specific conditions, such as program availability and social networks, as suggested by the push-pull factors (Li \& Bray, 2007; Mazzarol \& Soutar, 2002). Additionally, the decision to study in certain countries may be indirectly related to the broader social, economic, and political environment of both the origin and destination countries, as well as international relations between countries. Studies have found that students consider the image or reputation of a country when they decide where to study abroad (Ghazarian, 2016). For example, students who had significantly more positive views of South Korea and the United States chose to study abroad in those two countries, compared to their peers who chose to study abroad in other countries (Ghazarian, 2016). Indeed, similar studies suggest that uncertain political situations affect students' decisions to study in a specific country (Chen, 2008).

Despite a broad understanding of multiple factors that affect international students' choice of a destination country, several limitations impede a nuanced and systematic understanding of the phenomenon. First, international students are largely treated as a homogeneous group, and the factors associated with doctoral students' choices are not understood comprehensively, particularly in Canada. Secondly, the identified factors affecting international students' choices mostly focus on individual- and institutional-level factors. Much more scholarship is needed to examine institutional and national-level contexts (Chen, 2016). In addition, although there seems to be a consensus on the influence of political contexts and country image, it is not known how this af- 
fects students' choices compared to more direct factors. Moreover, despite these external factors, it is still not clear to what extent individuals have agency in making a choice as they weigh advantages and disadvantages in light of their academic interests, family influence, past experiences, and social relations. Lastly, it is unclear if students from different world regions or disciplines have different motivations to pursue doctoral studies abroad.

To fill this gap in the research, our study provides a more nuanced understanding by focusing on one category of students pursuing advanced degrees-international doctoral students in Canada, a fast-growing destination for international students. Moreover, we provide a more systematic and comprehensive account of factors affecting international students' choices, by including individual-, institutional-, and country-level factors. Importantly, we seek to understand the impact of political and geopolitical changes on international graduate students' decision making. Lastly, we explore potential variations by world regions and disciplines.

\section{Theoretical Framework}

To examine the complexity of decision making and the various factors influencing educational choice, we draw on two theoretical frameworks to guide our data analysis: the push-pull model and the decision mechanism of educational choices. We situate Gambetta (1984)'s individual decision-making process within the push-pull framework, which mainly focuses on the individual agency in the process of decision making.

The push-pull model is designed to explain the forces influencing migration: push factors from the country of origin and pull factors from the host country, such as the political, environmental, and economic context (Lee, 1966). When applied to student mobility, the push-pull model of international student choice states that the availability of local programs, the prestige of foreign degrees, immigration intention, reputation of foreign institutions, the perceptions of the foreign country of study, cost issues, and social links affect students' choices to study abroad (Mazzarol \& Soutar, 2002). We expect that these factors influence the decision making of international doctoral students in the Canadian context. However, we are interested in the extent to which certain factors are more visible in Canada and the identification of factors that influence the decision to pursue doctoral-level studies. To further examine the nuances of the factors, we divided them into three levels-individual-level, institutional-level, and country-level. Using this three-level mode, we discuss which push and pull factors are important and at which level.

To further investigate the dynamics in individual-level factors such as motivation and agency, we draw on Gambetta's framework (1984) that looks at educational decision making through a mechanism of three different approaches working together. These three theoretical approaches, used to examine influencing factors of educational decision, are the structuralist view, the push-from-behind view, and the attract-fromfront view. The structuralist view sees decision making as mainly channelled by external constraints, leaving little room for individual agency. The push-from-behind view assumes that unconscious factors propel decision making. It regards individual agents as inactive-either constrained by a lack of alternative choices or pushed from behind by causal factors, such as political turmoil in their home country. The attract-from-front view posits that educational decision making is a result of intentional choice and a reflection on future alternatives. When facing multiple choices, individual agents weigh them and make intentional choices that provide them future rewards attached to the action. Gambetta (1984) finds that none of the three views is sufficient alone to explain education decision making, and the mechanism cannot be reduced to only one factor from either the pushing or the pulling side. In this study, we examine individual agency by exploring how much flexibility students have in making a decision while considering other factors mentioned above. By examining the three views and the way in which these complex mechanisms work together, we seek to understand the extent to which these three perspectives work together in influencing the decision of international doctoral students in Canada.

Our conceptual framework is based on a model that combines education decision-making mechanisms and push-pull factors (Figure 1); neither one of the two theories alone is sufficient to account for the complexities of decision making. These complexities include both external factors and internal factors at the individual, institutional, and country levels. Using the first framework, a push-pull model, we look into the push factors from the countries of origin and also explore the pull factors. Given the limitations of the push-pull model in explaining mechanisms of decision making at the individual level, we include Gambetta's (1984) decision making mecha- 


\section{Figure 1}

\section{Conceptual Framework}

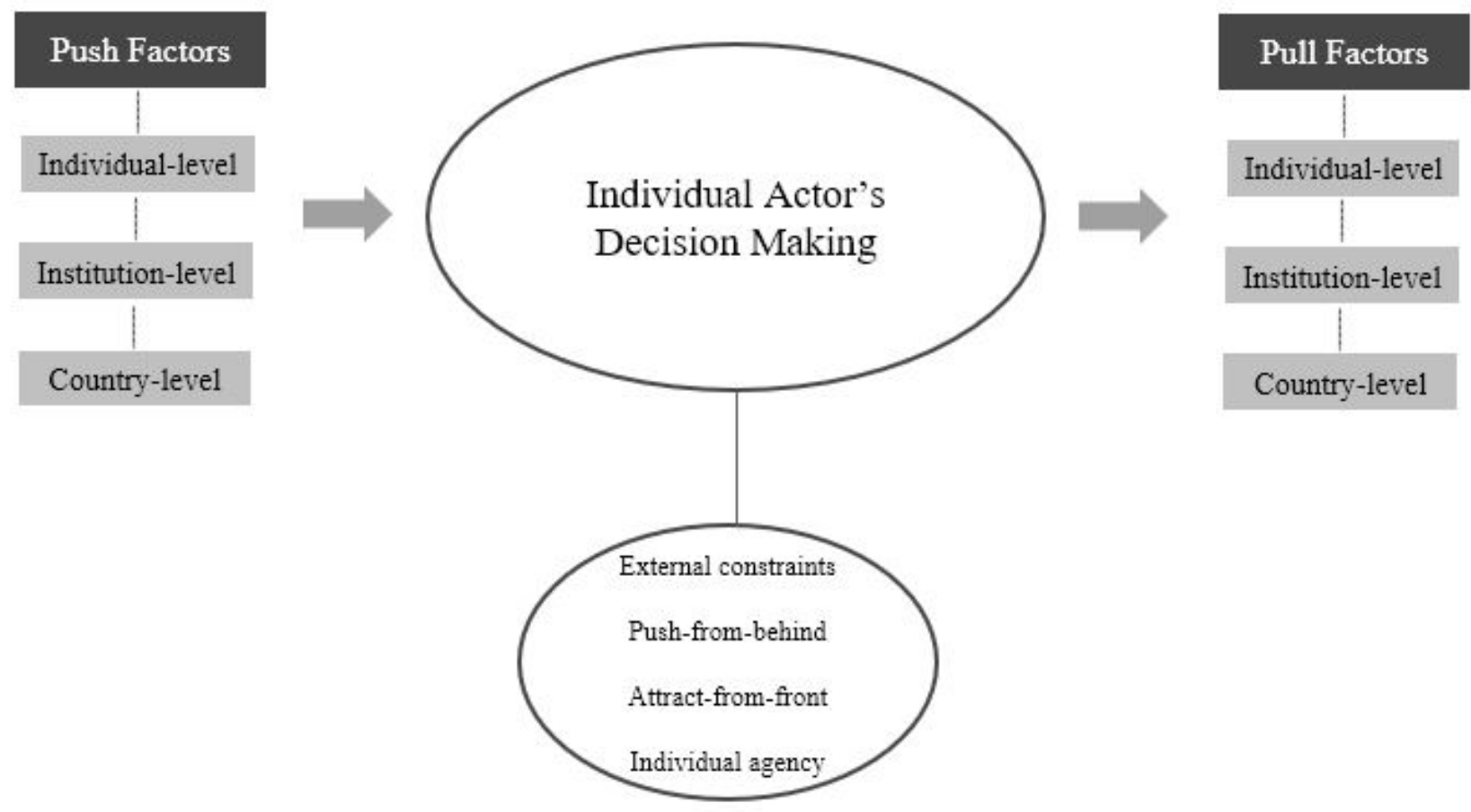

nism at the individual level. This mechanism involves three elements: external constraints, push-from-behind, and attract-from-front. We add the concept of individual agency in decision making to the individual level and systematize the model by differentiating among individual-, institutional-, and country-level factors, which the push-pull model does not. As we apply this model to our exploration of doctoral students' motivations to study in Canada, it contributes to a further examination of the complexity of decision making in socio-political-economic contexts and adds nuances and systematizes external and internal factors in the push-pull model.

\section{Methods}

This is a qualitative study using semi-structured interviews (Bogdan \& Biklen, 2007). Using purposeful snowball sampling (Merriam \& Tisdell, 2015), we contacted international doctoral students in our professional and personal networks and asked them to introduce our study to other international doctoral students who could contact us if interested. We selected 20 international doctoral students and conducted face-to-face interviews at Canadian University between December 2019 and February 2020. We reached data saturation (Hennink et al., 2019) after conducting 20 interviews. The interview participants are from different fields of study (humanities, social sciences, engineering, and natural sciences) and five different world regions (see Table 1). The interviews lasted from 30 minutes to one hour and included questions regarding factors influencing students' decision making in choosing their doctoral study institutions. The interviews were audio-recorded with permission and then transcribed into text. We entered the interview transcriptions into NVivo document analysis software (Silver \& Lewins, 2014) and carried out three rounds of coding and memoing. After testing a draft codebook, we arrived at a completed codebook (Table 2 in Appendix) that includes three parent codes corresponding to our conceptual framework: a three-level analysis of individual-, institutional-, and country-level factors. 


\section{Table 1}

Research Participants' Profile ( $N=20)$

\begin{tabular}{|c|c|c|}
\hline Category & $N$ & $\%$ \\
\hline \multicolumn{3}{|l|}{ Gender } \\
\hline Male & 9 & 45 \\
\hline Female & 11 & 55 \\
\hline \multicolumn{3}{|l|}{ Nationality } \\
\hline China (People's Republic) & 10 & 50 \\
\hline United States & 3 & 15 \\
\hline India & 3 & 15 \\
\hline Other & 4 & 20 \\
\hline \multicolumn{3}{|l|}{ Region } \\
\hline Central Asia & 1 & 5 \\
\hline East Asia & 11 & 55 \\
\hline South and Southeast Asia & 4 & 20 \\
\hline North America & 3 & 15 \\
\hline West Africa & 1 & 5 \\
\hline \multicolumn{3}{|l|}{ Disciplines } \\
\hline Humanities & 4 & 20 \\
\hline Social Sciences & 8 & 40 \\
\hline Natural Science & 4 & 20 \\
\hline Engineering & 4 & 20 \\
\hline
\end{tabular}

Note. $N=$ the total number of participants; $\%=$ percentage of participants

\section{Findings}

\section{Influential Factors}

Certain codes and child codes had higher frequency than others during the coding process (See Table 3 in Appendix). In the interviews, institutional-level codes were most commonly noted (210 times), followed by individual-level (127) and country-level codes (87) (See Figure 2 in Appendix). The top three child codes were all at the institutional level: faculty member, location, and funding. Among the top 10 sub-theme codes, five were institutional-level factors, three were individual-level factors, and two were country-level factors.

\section{Individual-level Factors}

At the individual level, we identified four factors that occur most frequently in the interviews: individual motivation, preparedness, social background, and personal and family finance. 


\section{Individual Motivation}

Regarding individual motivation, we analyzed the themes related to students' personal experiences, interests, and capabilities. Among them, academic interest served as a crucial factor as, for many students, doing a $\mathrm{PhD}$ is motivated mainly by passion and personal research interest. Some students were drawn to certain faculty, not only because of shared academic interest, but because of their particular approaches to research and scholarship. For example, Feng, a Chinese student, said, "One particular reason I picked Canada University is because one of my previous teachers graduated from Canada University. I studied under her supervision. She was always a model for me as a scholar."

Second to academic interest was the notion of aspiration: a student's desire to seek out challenging new life experiences and to break the status quo. For example, Daniel (North America) reports, "Frankly, I was just desperate for a challenge...I desperately wanted to do something useful with my acquired skills and innate talents." Ning (China) also reported his desire to seek a new challenge: "My motivation is to make changes. I think that I have learned enough from my previous work."

\section{Academic and Psychological Preparedness}

Many participants also mentioned the importance of previous life, work, and academic preparation, as they weigh the difficult decision to study abroad. Some noted their experience in universities or workplaces offered them a chance to interact with English-speaking countries and broaden their horizons. Others described research and lab experience or participation as psychological preparation for undertaking research and for developing interest in theoretical work. Mei (China) described the influence of her previous work in international programming: "The international program experience really helped me to think that way. It helped me to catch up to this program. And also, since we were doing an international program back in China, our working language was English."

\section{Social Background}

Family influence, network, and peer influence were the main themes in this category. Among them, family influence played a significant role, as several participants mentioned that their choice of programs and pursuit of higher education are influenced by family preferences, parental support, and parent's professional and educa- tional backgrounds. Emma (US) described the influence of her family, saying "I grew up in a very stable middle-class household and both of my parents have graduate degrees, which I know is definitely a huge factor from a young age in making me think I could take an academic path."

Peer influence served as another important factor when students make decisions. Some mentioned that the trajectories of the senior students or their romantic partners influence their decision making of studying abroad. In addition, personal networks can be another factor when they consider a specific program or supervisor. Hao (China) said personal networks shaped his choice: "As for why Canada University, my supervisor recommended it, because my master supervisor knows the current supervisor there. Then I became his first PhD student."

\section{Personal and Family Finance}

Several students mentioned explicitly that financial factors are a major concern when considering pursuing a $\mathrm{PhD}$, and only consider the institutions that offer scholarships. Jian (China) indicated that he only considered institutions with funded programs and scholarships. Trish (India), described the influence of her family financial situation:

Economic factors [matter] for sure. No one in my family has done a PhD before or a bachelor's degree before. My sister did a master's [degree] for the first [time]. She waited for quite a few years to do that, because we were not financially stable.... My dad was retiring so I didn't want to be any sort of financial problem [for my family]. I did have opportunities to work in India. I did apply for jobs, and they were good paying jobs for India.

\section{Country-level Factors}

Our analysis revealed two major factors that fall at the country level: immigration and political climate. These two factors were intertwined in students' decision-making process to pursue their PhD. Eventually, Canada was often chosen because of its favourable immigration policies compared to other English-speaking countries, and comparatively stable political climate compared to its neighbour, the United States. 


\section{Immigration}

Immigration was an important factor when students consider studying abroad. Some students explicitly mentioned that they chose to go to Canada because its immigration policies are friendly to international students, especially relative to the United States. This was also in consideration of their future plans vis-à-vis family members. Mei, for example, explicitly referred to immigration as the main purpose of studying in Canada.

The decision to apply for Canadian universities comes along with this immigration purpose....in terms of immigrant countries, America is not optimistic. Canada was my best choice at that time. So, I decided to get a chance to study and...find a way to immigrate to Canada.

Immigration motivated students differently according to academic discipline. Only one student in the natural sciences mentioned that he preferred the institution in Canada because of immigration policies. Four students in the social sciences and one student in the humanities mentioned immigration and some of them considered immigration as an important factor in their decision making. For example, a student in social science candidly responded that she primarily wanted to immigrate to Canada through her PhD program.

\section{Political Climate}

Interestingly, the political climate was an important factor for some students' decisions to go to one country instead of another. Although not all students considered the political environment, some students did so by comparing the political climate in the United States to that in Canada. Restrictive immigration policies under the Trump administration have made it harder for international students to enter the United States, while the administration's anti-immigrant rhetoric may have made students feel unwelcome and uncertain about pursuing their studies or careers in the United States (Johnson, 2018). Feng's quotations showed her sincere doubts when she was considering studying in the United States and why she eventually chose Canada. She says: "I was applying when the trade war between the United States and China was still ongoing. That created a lot of uncertainty within my family and myself. What would be the prospect if I go to the United States?"

Abdoulaye, though he had already enrolled in a PhD in Canada, was unable to take up a fellowship at an elite US institution because of the difficulty he faced in securing a visa. He connected this problem to the Trump administration's immigration and travel restrictions, particular for students from Muslim or Arab backgrounds: "It's because of the current administration. As you know I had this visiting fellowship at [elite US institution] but I couldn't take it up. Because I didn't get the visa."

\section{Regional Variations}

The 20 interview participants came from countries that can be grouped into five regions: Central Asia, East Asia, South and Southeast Asia, and North America (see Table 1 ). While these groupings are imperfect and contain a varying number of interviews, they reveal geographic or regional trends in student motivations. As shown in Table 4 (see Appendix), there is variation in the frequency and ranking of themes, though there are some similarities across regions. For example, in three of the five regions, institutional themes occurred most frequently in student interviews. Notably, the only region to have country-level codes as the most common code was West Africa, while the only region to have individual-level codes as the most common code was North America.

There was great variation in child codes among the five regions, as no two regions displayed the same rank or number of child code references, but there were some overlaps between regions. The frequency of subcodes also tended to follow the frequency of parent codes. For example, institutional sub-codes, especially "faculty member," were most common in both East Asia and South and Southeast Asia, where institutional-level codes were most frequent overall. For West Africa and Central Asia, country-level political factors were the most frequent child codes.

The educational pathway of Abdoulaye (West Africa) was strongly shaped by country-level factors, specifically political factors and immigration. His decision to pursue his master's in Canada was influenced by his family's decision to immigrate to French-speaking Canada, itself a decision related to their linguistic background (French). His decision to stay in Canada was indirectly and directly affected by the rhetoric and immigration policies of former US President Trump.

That individual-level factors predominated among some North American students could reflect the region's individualistic culture. One student from the region em- 
phasized her personal research interests:

From an early age I knew I wanted to pursue astrophysics.... I also wanted to leave my home state to go somewhere generally warmer.... CU matched my research interest the best with professors.... The research is really important to me. I've always been fascinated by questions about the early universe.

Another North American student, Daniel, talked about his desire to have an academic challenge as motivation to pursue his PhD. For him, the country was not as important as being able to pursue his work and research: "Frankly, I was just desperate for a challenge, desperate to feel like I was in a place that mattered, where useful work was being done."

In both the East Asia and South and Southeast Asia regions, where institutional parent codes predominated, "faculty member" was the most frequent child code. Ting (East Asia), for example, describes how an email exchange with a faculty member led them to accept Canadian University: "I got this email from my current supervisor after a while.... So, he was the one who really reached out to me, and I was super flattered and surprised."

\section{Discussion and Conclusion}

In this study, we interview 20 international students about their decision to pursue a PhD in Canada. Applying our three-level analysis, we discuss findings from each layer below and its relevance to our conceptual framework that modifies the push-pull model (see Figure 1).

\section{Individual Level}

At the individual level, we find the factors influencing students' decision making are interwoven into the external and internal aspects of individuals' complex social webs. These aspects include individual motivation, academic preparedness, social backgrounds, and personal and family finances. Rather than being influenced directly by push or pull factors, the decision to do a PhD is more influenced by individual academic interest and motivation, family members and peers, personal and family financial capital or opportunities, and skills or abilities gained from past experiences. Viewed through Gambetta's mechanism of education decision making (1984), the strong influence of the environment, such as a supervisor changing institutions or the strong aspiration of studying abroad in the family, can be regarded as the push from behind, while the motivation of making a change in career and aspiring to realize their academic passion is closer to the view of attracting from the front.

Notably, some students say that they had no choice at all in their decision. The combination of background, experience, and motivations act as constraints, pushing them to a point where there seems to be only one direction forward. This situation can be understood through the lens of the constraints from the external environment, in which the decision making is mainly channelled by external factors, leaving no room for individual agency or flexibility in decision making. However, in most situations, it is a combination of the three: pushing from behind, pulling from the front, and constraints from the external environment. By no means is the decision influenced by a single factor, as most students admit that the decision-making process is very challenging and complex. Our use of the individual decision-making mechanism, particularly at the individual level, complements the push-pull model which has largely overlooked the complex process of educational decision making.

\section{Institutional Level}

Institutional-level factors are primarily pull factors for students and are the most dominant among the three levels. Among our interviewees, the most reported institutional-level factors are faculty, strength of academic program, and funding.

Frequently, these factors supersede political or social factors. For example, despite rising Chinese-United States tensions and restrictive immigration policies, Chinese students are often still drawn to apply to US universities because of their ranking, funding opportunities, and the individual faculty members. For many students, two factors-(1) funding, and (2) acceptance into a program-are determining factors. These findings echo Chen's (2008) findings that graduate students are more likely to make decisions about international study based on programs versus location.

In addition, we find new evidence that suggests funding as a factor works in a more nuanced way. Students in the social sciences and humanities tend to be more concerned with funding and elaborate on the importance of funding more often than students in the 
natural sciences and engineering. This finding adds disciplinary nuances to the current literature on factors influencing students' decision making. However, future research could examine why there are disciplinary differences in the consideration of funding in international students' decision making.

\section{Country Level}

We also find some influence of national policies on international students' decision making, particularly immigration and political climate. Friendly immigration policies for international students, such as in Canada, serve as a strong pull factor. This is especially salient when students compare immigration opportunities alongside educational ones. This, however, seems to play out differently across disciplines. Immigration tends to be more important for students in the social sciences and humanities, compared to students in the natural sciences and engineering. In addition, students from West Africa and Central Asia tend to stress political factors more than students from other regions. This finding is an indication of the impact of immigration policy on students' decision making, which is further complicated by students' disciplines and country of origin.

In addition, we observe that restrictive and often erratic immigration policies or anti-immigrant rhetoric in the United States create uncertainty and doubt for students as they consider studying in the United States. Such rhetoric and policies include Executive Orders restricting travel from seven majority Muslim countries, often referred to as the Muslim Ban, disparaging references to immigrants from certain African and Caribbean countries, and greater scrutiny of study visas and universities overseas ties with Chinese universities and the government (Fischer, 2019; Lanktree, 2018; Pierce \& Meissner, 2017). We argue that these discouraging policies create further uncertainty and negatively affect students' attitudes toward the United States.

Therefore, we see some evidence of Chen's description of "aversive factors" that deter international students (Chen, 2016, p. 130). In this case, a student may be attracted to the United States because of rankings and existing social networks, but ultimately may be pushed away because of immigration policy and political climate. This phenomenon seems especially relevant to Canada, as many students discussed Canada and the United States as their top study abroad choices. Several students opted to study in Canada after being rejected from their first-choice graduate programs in the United States, not receiving sufficient funding, or feeling uncertain about US immigration policies and political climate.

These factors, we argue, might partially explain the substantial growth of international students in Canada. The interviews were conducted prior to the global COVID-19 pandemic which is a critical moment that creates further uncertainty in international student mobility. Specifically, the Trump administration's decisions sent unfriendly signals to international students. We contend that the Trump administration's decisions, though now partially reversed by President Biden, have injected uncertainty in international students regarding the attractiveness of the United States as a destination country and may benefit countries such as Canada. Future research may explore the decision making of international doctoral students in other countries, particularly their consideration in light of restrictive US policies toward immigration and international students in the Trump era. Future research could also explore the extent to which COVID-19 accelerates the trend in international student mobility, where more destination countries are available in the global south. Our research confirms Chen's (2007) findings that international students prioritize programs over countries, with one caveat. Many of the students in our study applied to a number of programs in the United States and Canada. Their eventual decisions are sometimes guided by politics, immigration policies, and reputation (Ghazarian, 2016) of individual countries, but more often by supervisor, ranking of program, available funding, and, simply, which program accepted them. How students prioritize study abroad destinations may also differ by their country of origin.

Applying our theoretical framework, there are, generally, more pull factors than push factors when students go about choosing an institution, including the prestige, ranking, city location, and future opportunities for working or immigrating. Push-pull factors operate more strongly at the institutional and country levels than at the individual level. All the factors working together shape the individual student's decision (Figure 1). Importantly, our empirical findings confirm the importance of modifying the frequently adopted push-pull models in international student decision making. Specifically, it is important to include a three-level analysis, particularly adding country-level factors and explaining mechanisms at the individual level, which our conceptual framework does. 
We see that the three-level analysis is a useful frame to understanding student motivation. It is essential, however, to understand how these three levels may interact with each other and can operate as both push or pull factors.

Our findings contribute new data to the understanding of the push-pull model in changing, uncertain times for international higher education. We also advance the literature on international student mobility through a modified, more nuanced push-pull model that accounts for the many factors at the individual, institutional, and country levels-as well as the interplay of those factors for each student. Our move to complicate the push-pull model is in line with other authors who find a complex web of factors that shape international student experiences that may also vary by country, program/discipline, and level of study (Chen, 2008). Particularly, our findings on regional and disciplinary variations highlight important nuances in international doctoral students' decision making.

Our research provides insight for the higher education administrators and governments as they try to attract more international students and reap the financial, intellectual, and cultural benefits of internationalization (Fischer \& Green, 2018). It is also useful for international higher education practitioners to understand the decision-making processes of international doctoral students in changing and uncertain times. Particularly, it calls for considerations of regional and disciplinary differences in policy making and in institutions' practices in student service.

This study focuses on academic-stream doctoral students at one public research university located in a large city in Canada, and therefore, the findings may not be applicable to institutions in other contexts, such as those located in rural areas. Additionally, the factors affecting doctoral students in professional streams might be different, which is an area for future research. Future research may also investigate the interplay of individual-, institutional-, and country-level factors influencing international students' decision making in different types of institutions in the Canadian context. Moreover, our data collection ended before the global pandemic of COVID-19. Many changes have occurred and will continue to evolve in global and national politics and economic development. These changes will undoubtedly affect students' choice of destination countries, and fu- ture research may probe how international students are impacted by the global pandemic.

\section{Acknowledgements}

The authors contributed equally to this research and manuscript. We thank the two anonymous reviewers for their insightful feedback on our manuscript. Part of this research was presented at the China Higher Education Conference at the University of Manchester, United Kingdom. We would like to extend our sincere thanks to our interview participants whose involvement made this research possible. We also wish to acknowledge the land on which the University of Toronto operates. For thousands of years, it has been the traditional land of the Huron-Wendat, the Seneca, and the Mississaugas of the Credit. Today, this meeting place is still the home to many Indigenous people from across Turtle Island and we are grateful to have the opportunity to work on this land.

\section{References}

Altbach, P. G. (2007). Globalization and the university: Realities in an unequal world. In J. J. F. Forest \& P. G. Altbach (Eds.), International handbook of higher education (pp. 121-139). Springer.

Altbach, P. G., \& Knight, J. (2007). The internationalization of higher education: Motivations and realities. Journal of Studies in International Education, 11(3-4), 290-305. https://doi. org/10.1177/1028315307303542

Barnett, G. A., Lee, M., Jiang, K., \& Park, H. W. (2016). The flow of international students from a macro perspective: A network analysis. Compare: $A$ Journal of Comparative and International Education, 46(4), 533-559. https://doi.org/10.1080/03057925.2015.1 $\underline{015965}$

Bogdan, R., \& Biklen, S. K. (2007). Qualitative research for education: An introduction to theories and methods (5th ed.). Pearson.

Buckner, E., Clerk, S., Marroquin, A., \& Zhang, Y. (2020). Strategic benefits, symbolic commitments: How Canadian colleges and universities frame internationalization. Canadian Journal of Higher Education, 50(4), 20-36. https://doi.org/10.47678/ 
cjhe.vi0.188827

Chellaraj, G., Maskus, K. E., \& Mattoo, A. (2008). The contribution of international graduate students to US innovation. Review of International Economics, 16(3), 444-462. https://doi.org/10.1111/j.14679396.2007.00714.X

Chen, J. M. (2016). Three levels of push-pull dynamics among Chinese international students' decision to study abroad in the Canadian context. Journal of International Students, 7(1), 113-135. https://files. eric.ed.gov/fulltext/EJ1125723.pdf

Chen, L. H. (2007). Choosing Canadian graduate schools from afar: East Asian students' perspectives. Higher Education, 54(5), 759-780. https://doi. org/10.1007/s10734-006-9022-8

Chen, L. H. (2008). Internationalization or international marketing? Two frameworks for understanding international students' choice of Canadian universities. Journal of Marketing for Higher Education, 18(1), 1-33. https://doi. org/10.1080/08841240802100113

Chen, T. M., \& Barnett, G. A. (2000). Research on international student flows from a macro perspective: A network analysis of 1985, 1989 and 1995. Higher Education, 39(4), 435-453. https://doi. org/10.1023/A:1003961327009

Choudaha, R. (2017). Three waves of international student mobility (1999-2020). Studies in Higher Education, 42(5), 825-832. https://doi.org/10.1080/ 03075079.2017.1293872

Cooper, L. (2017). Attracting international talent. RBC Economics Research. https://www.rbccm.com/ assets/rbccm/docs/news/2017/Attracting-International-Talent.pdf

De Wit, H., \& Merkx, G. (2012). The history of internationalization of higher education. In D. K. Deardorff, H. de Wit, J. D. Heyl, \& T. Adams (Eds.), The SAGE handbook of international higher education (pp. 4357). Sage. https://doi.org/10.4135/9781452218397. n3

Fischer, K. (2019, September 4). Visas revoked at the border put a new dent in American higher ed's image abroad. The Chronicle of Higher Education. https://www.chronicle.com/article/visas-revoked-atthe-border-put-a-new-dent-in-american-higher-edsimage-abroad/

Fischer, S., \& Green, W. (2018). Understanding contextual layers of policy and motivations for internationalization: Identifying connections and tensions. Journal of Studies in International Education, 22(3), 242-258. https://doi. org/10.1177/1028315318762503

Gambetta, D. (1984). Decision mechanisms: Educational choices in Italy. Social Science Information, 23(2), 275-323. https://doi. org/10.1177/053901884023002002

Gao, Y. (2019). Experiences of Chinese international doctoral students in Canada who withdrew: A narrative inquiry. International Journal of Doctoral Studies, 14, 259-276. https://doi.org/10.28945/4240

Ghazarian, P. G. (2016). Country image and the study abroad destination choice of students from Mainland China. Journal of International Students, 6(3), 700-711. https://doi.org/10.32674/jis.v6i3.350

Government of Canada. (2020). I recently graduated as an international student in Canada. Can I apply for permanent residence? https://www.cic.gc.ca/english/helpcentre/answer.asp? qnum $=519$ \&top $=15$

Hennink, M. M., Kaiser, B. N., \& Weber, M. B. (2019). What influences saturation? Estimating sample sizes in focus group research. Qualitative Health Research, 29(10), 1483-1496. https://doi. org/10.1177/1049732318821692

Institute of International Education. (2020). Project Atlas 2020 release. https://iie.widen.net/s/rfw2c7rrbd/ project-atlas-infographics-2020

Jafar, H., \& Legusov, O. (2021). Understanding the decision-making process of college-bound international students: A case study of greater Toronto area colleges of applied arts and technology. Community College Journal of Research and Practice, 45(7), 463-478. https://doi.org/10.1080/10668926.2 $\underline{020.1723740}$

Johnson, K. (2018). Opportunities \& anxieties: study of international students in the Trump era. Lewis \& Clark Law Review, 22(2), 413-440. https://hei- 
nonline.org/HOL/Page?handle=hein.journals/lewclr22\&id=433\&collection=journals\&index=\#

Lanktree, G. (2018, January 12). Trump's "shithole" countries are worth $\$ 46.6$ billion in trade to America. Newsweek. https://www.newsweek.com/trumpsshit-hole-countries-are-worth-466-billion-tradeamerica-779324

Lee, E. S. (1966). A theory of migration. Demography, 3(1), 47-57. https://doi.org/10.2307/2060063

Li, M., \& Bray, M. (2007). Cross-border flows of students for higher education: Push-pull factors and motivations of mainland Chinese students in Hong Kong and Macau. Higher Education, 53(6), 791-818. https://doi.org/10.1007/s10734-005-5423-3

Maier, R., \& Robson, K. (2020). Exploring university-to-college transfer in Ontario: A qualitative study of non-linear post-secondary mobility. Canadian Journal of Higher Education/Revue Canadienne d'enseignement Supérieur, 50(1), 82-94. https:/l doi.org/10.7202/1069653ar

Mascitelli, B., \& Chung, M. (2019). Hue and cry over Huawei: Cold war tensions, security threats or anti-competitive behaviour? Research in Globalization, 1, 100002. https://doi.org/10.1016/j. resglo.2019.100002

Mazzarol, T., \& Soutar, G. N. (2002). "Push-pull” factors influencing international student destination choice. International Journal of Educational Management, 16(2), 82-90. https://doi. org/10.1108/09513540210418403

Merriam, S. B., \& Tisdell, E. J. (2015). Qualitative research: A guide to design and implementation. John Wiley \& Sons.

Pandit, K. (2013). International students and diversity. In H. C. Alberts \& H. D. Hazen (Eds.), International students and scholars in the United States. Palgrave Macmillan. https://doi. org/10.1057/9781137024473 7

Pierce, S., \& Meissner, D. (2017). Trump executive order on refugees and travel ban: $A$ brief review. Migration Policy Institute. https://www.migrationpolicy. org/sites/default/files/publications/Trump-EO-Refu-
gees-TravelBan-FINAL.pdf

Sá, C. M., \& Sabzalieva, E. (2018). The politics of the great brain race: Public policy and international student recruitment in Australia, Canada, England and the USA. Higher Education, 75(2), 231-253. https://doi.org/10.1007/s10734-017-0133-1

Shields, R. (2013). Globalization and international student mobility: A network analysis. Comparative Education Review, 57(4), 609-636. https://doi. org/10.1086/671752

Silver, C., \& Lewins, A. (2014). Using software in qualitative research: A step-by-step guide. Sage.

UNESCO Institute for Statistics. (2021). Number and rates of international mobile students. http://data. uis.unesco.org/

Wu, H. (2020). Decision-making process of international undergraduate students: An exploratory narrative inquiry into reflections of Chinese students in Canada. ECNU Review of Education, 3(2), 254-268. https://doi.org/10.1177/2096531119890143

\section{Contact Information}

Michael O'Shea

michael.oshea@mail.utoronto.ca 